\title{
SPONTANEOUS VARIEGATION FOR PERIANTH COLOUR IN WILD ANEMONE CORONARIA
}

\author{
A. HOROVITZ and D. ZOHARY \\ Department of Botany, The Hebrew University, Jerusalem, Israel
}

Received 21.xii.65

WILd anemone populations in Israel (Anemone coronaria L., diploid, $2 n=\mathrm{I} 6$ ) are sometimes markedly polymorphic in perianth colouration. Scarlet-flowered plants are always present and usually frequent in any local population. In the south and the more arid parts of the country they are the sole colour type. In the north (Galilee, Samaria) wild populations are often polymorphic and comprise numerous nonscarlet types in addition to the scarlet one; these range from white through pink to purple and various hues of violet. $A$. coronaria is protogynous and thus apparently largely cross-pollinated.

Examination of polymorphic populations in the north of Israel revealed that, while part of the non-scarlet plants are homogeneously coloured, others are characterised by a spot variegation of the perianth with random scarlet spots present on either epidermis. Usually there are only a few scattered spots in a single flower. They are mostly small and vary in size from a single epidermal cell to a group of 30 to 40 . If composed of a number of cells, such scarlet sectors are characteristically elongated radially, and their two ends taper where the background tissue closes in on the scarlet-pigmented one.

In order to clarify whether the scarlet spot variegation has a genetic basis, breeding experiments were carried out with homogeneously coloured and variegated plants. The cross combinations produced and the results obtained are summed up in table $\mathrm{I}$. These results are interpreted as follows:

(i) From progenies obtained in scarlet $\times$ scarlet and scarlet $\times$ homogeneous non-scarlet crosses (combinations $I$ and 3 ) it is obvious that the scarlet condition is recessive to the non-scarlet one and is apparently controlled by a single locus.

(ii) Homogeneous non-scarlet individuals tested bred true (combination 2). When crossed to scarlet they yielded only non-scarlet and mostly variegated offspring (combination 3 ). All non-scarlet individuals tested in these combinations ( 8 plants) are thus regarded as dominant homozygotes.

(iii) Variegated non-scarlet individuals tested segregated both when intercrossed (combination 4) and when crossed to scarlet (combination 5), yielding scarlet-flowered in addition to non-scarlet progeny. Accordingly all variegated individuals tested (ro plants) are assumed to be heterozygous for the scarlet gene.

Results obtained from cross combination 6 also conform with the 
assumption that a single gene difference is involved here, and that spot variegation is characteristic of heterozygotes only. Combinations 4 and 5 show that heterozygosity is not invariably detected, and that the "penetrance" of spotting in heterozygotes here is in the order of 85 per cent. This however still means that by checking on variegation one can distinguish heterozygotes to a large extent from homozygous (dominant) plants.

If scarlet spot variegation is indeed confined to heterozygous individuals, there are two plausible explanations for it: (a) somatic

TABLE I

Tests on scarlet spot variegation

\begin{tabular}{|c|c|c|c|c|}
\hline \multirow{3}{*}{ Cross combination } & \multicolumn{4}{|c|}{ Progeny obtained } \\
\hline & \multirow{2}{*}{ Total } & \multicolumn{2}{|c|}{ Non-scarlet } & \multirow{2}{*}{ Scarlet } \\
\hline & & Homogeneous & Variegated & \\
\hline$\times$ scarlet & 129 & - & - & 129 \\
\hline $\begin{array}{l}\text { 2. non-scarlet } \\
\text { homogeneous }\end{array} \times \begin{array}{l}\text { non-scarlet } \\
\text { homogeneous }\end{array}$ & 114 & 114 & - & - \\
\hline $\begin{array}{l}\text { 3. non-scarlet } \\
\text { homogeneous } \\
\text { and reciprocal combination }\end{array}$ & 198 & 29 & 169 & - \\
\hline 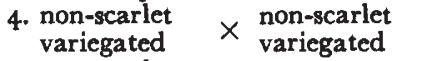 & 35 & 4 & 22 & 9 \\
\hline 5. non-scarlet $\times$ scarlet & $4^{8}$ & 5 & 14 & 29 \\
\hline $\begin{array}{l}\text { 6. non-scarlet } \\
\text { variegated }\end{array} \times \begin{array}{l}\text { non-scarlet } \\
\text { homogeneous }\end{array}$ & 204 & 114 & 90 & - \\
\hline
\end{tabular}

gene mutation, as assumed in the case of the pal locus in Antirrhinum majus (Harrison and Fincham, I964); (b) mosaic is produced by occasional spontaneous somatic loss of a chromosome or chromosomal segment harbouring the dominant allele, thus producing a pseudodominance effect similar to the white spot effect in Nicotiana tabacum (Moav and Cameron, 1960; Moav, 1961). The tapering growth pattern of scarlet sectors as well as their smallness (large scarlet stripes are a very rare feature) seem to point to developmental sublethality. If indeed the shape of the spot reflects reduced viability-it would be hard to explain the "mutant" sectors as resulting from simple gene mutation. The fact is that in segregating families scarlet (i.e. the homozygous recessive) individuals are as vigorous as their non-scarlet sibs and develop normal flowers. The shape of the spots coupled with the occurrence of normal scarlet plants thus present circumstantial evidence in favour of somatic chromosomal aberrations. But obviously the matter needs further exploration. 
Acknowledgment.-We wish to acknowledge the help of Mr Giora Simchen in the examination of natural populations which initiated the present study.

\section{REFERENCES}

MOAV, R., AND CAMERon, D. R. 1960. Genetic instability in Nicotiana hybrids. I. The expression of instability in $\mathcal{N}$. tabacum $\times \mathcal{N}$. plumbaginifolia. Am. Fourn. Bot., 47 , $87-93$.

MOAV, R. I96r. Genetic instability in Nicotiana hybrids. II. Studies of the Ws $(p b g)$ locus in $\mathcal{N}$. plumbaginifolia in $\mathcal{N}$. tabacum nuclei. Genetics, 46 , ro6g-ro87.

HARRISON, B. J., AND FINCHAM, J. R. s. 1964. Instability at the pal locus in Antirrhinum majus. I. Effects of environment on frequencies of somatic and germinal mutation. Heredity, 19, 237-258. 